\title{
SYMMETRICAL BIFURCATION OF THE Alethopteris urophylla FROND
}

\author{
Jean-Pierre LAVEINE ${ }^{1}$ and Thierry OUDOIRE ${ }^{2}$ \\ Musée de Géologie de la Ville de Lille, 19 rue de Bruxelles, F-59000 Lille, France. \\ 1 jplaveine@mairie-lille.fr; Jean-Pierre.Laveine@wanadoo.fr \\ 2 toudoire@mairie-lille.fr; th.oudoire@voila.fr
}

Laveine, J.-P. \& Oudoire, T. 2009. Symmetrical bifurcation of the Alethopteris urophylla frond. [Bifurcación simétrica en el fronde de Alethopteris urophylla.] Revista Española de Paleontología, 24 (2), 121-131. ISSN 0213-6937.

\begin{abstract}
A symmetrical bifurcation of an Alethopteris urophylla frond from the Pennsylvanian (Upper Carboniferous) of the Northern France coalfield shows some still-attached remains of foliage. Such rare specimens contribute, step by step, to a better understanding of the frond architecture of the genus Alethopteris, which is of the bifurcatepinnate type. A few complementary general comments are given.
\end{abstract}

Key words: Palaeobotany, Carboniferous, Medullosales, Alethopteris, frond architecture.

\section{RESUMEN}

Se describe un ejemplar de fronde de Alethopteris urophylla que muestra una bifurcación simétrica así como algunos restos de pinnas aún adheridas. Este ejemplar procede del Pensilvánico (Carbonífero Superior) de la cuenca minera del Norte de Francia. Estos hallazgos excepcionales contribuyen, poco a poco, al mejor conocimiento de la construcción de una fronde del género Alethopteris, de tipo bifurcado-pinatífido. Se añaden algunos comentarios generales

Palabras clave: Paleobotánica, Carbonífero, Medullosales, Alethopteris, arquitectura del fronde

\section{RESUME}

Une bifurcation symétrique d'une fronde d'Alethopteris urophylla en provenance du Pennsylvanien (Carbonifère supérieur) du bassin houiller du Nord de la France montre quelques restes de feuillage encore attachés. De tels spécimens, rares, contribuent petit à petit à une meilleure compréhension de l'architecture de la fronde, qui est de type bifurqué-pinné. Quelques commentaires généraux complémentaires sont fournis.

Mots-clés: Paléobotanique, Carbonifère, Médullosales, Alethopteris, architecture de fronde.

\section{INTRODUCTION}

Zeiller (1888: 226-227) suggested that the frond of Alethopteris lonchitica (Schlotheim, 1804, 1820) probably exhibited a symmetrical dichotomy. His argument was based on a specimen (Zeiller, 1886: pl. 31) showing a correlation between the variation in size of the attached inner secondary pinnae and their location inside the presumed bifurcation. Unfortunately, owing to its large dimensions, the specimen could only be partly illustrated, and the bifurcation itself was not represented. The lack of formal proof for the connection of the primary rachides probably entailed that little attention was paid to Zeiller's suggestion. Accordingly, most reconstructions of the Alethopteris Sternberg, 1825 frond were essentially proposing a strictly pinnate, non-dichotomizing frond (e.g. Buisine, 1961: figs 2a, 6; Laveine, 1967: fig. 2; Wnuk \& Pfefferkorn, 1984: fig. 13).

Fortunately, the record of a specimen of Neuralethopteris Cremer, 1893, exhibiting a frond main bifurcation with still-attached remains of foliage (Laveine et al., 1993: pl. 1), together with the record (Goganova et al., 1993) 
of remarkable remains of Cardioneuropteris Goganova, Laveine, Lemoigne \& Durante, 1993, allowed Laveine et al. (1993) to reconsider formally the frond architecture of the taxa of the whole group. The latter authors provided a fairly extensive discussion on the matter, and proposed new frond reconstructions exhibiting naked petioles and a main symmetrical bifurcation (Laveine et al., 1993: fig. 3; Goganova et al., 1993: fig. 6). Laveine (1997: fig. 2) proposed the denomination 'bifurcate-pinnate' for such fronds. However, the assignment of Alethopteris to that type of frond was proposed by Laveine et al. (1993) only by analogy. They could only present (Laveine et al., 1993: pl. 3, fig. 1) a specimen showing two fragments of large frond bifurcations devoid of attached foliage, and ascribed them to the genus Alethopteris solely on the basis of association. The relationship therefore remained uncertain. Accordingly, Zodrow (2002: 177) noted that 'a bifurcate alethopterid frond, ..., remains to be demonstrated'. This remark emphasizes that decisive specimens are hard to come by. Consequently, any specimen that brings decisive information on frond organization is worth recording.

\section{MATERIAL AND METHODS}

The specimen described herein (accession number: MBL 630905) belonged initially to the collections of the Laboratory of Palaeobotany of Lille University. It was rediscovered during the transfer of the collections to the Lille Coal Museum in 2008. Apparently, this specimen was collected a long time ago from the coalfield of Northern France, probably from a spoil heap. No precise localisation is available.

The specimen required only slight mechanical degaging and was photographed using plain-light illumination. Terminology for frond architecture follows that used in Laveine (1997).

\section{DESCRIPTION}

The slab is $24 \mathrm{~cm}$ long and $25 \mathrm{~cm}$ wide. It bears the bifurcate fragment of an Alethopteris frond. The petiole, at least $22 \mathrm{~mm}$ wide, is only preserved in its top part, for 25 $\mathrm{mm}$ from the inside angle of bifurcation (Figs 1, 2a, 2b). The two primary rachides are at $\mathrm{ca} 50^{\circ}$ angle. The right primary rachis is preserved straight in $180 \mathrm{~mm}$ length, after which it is bent slightly and broken off $20 \mathrm{~mm}$ further

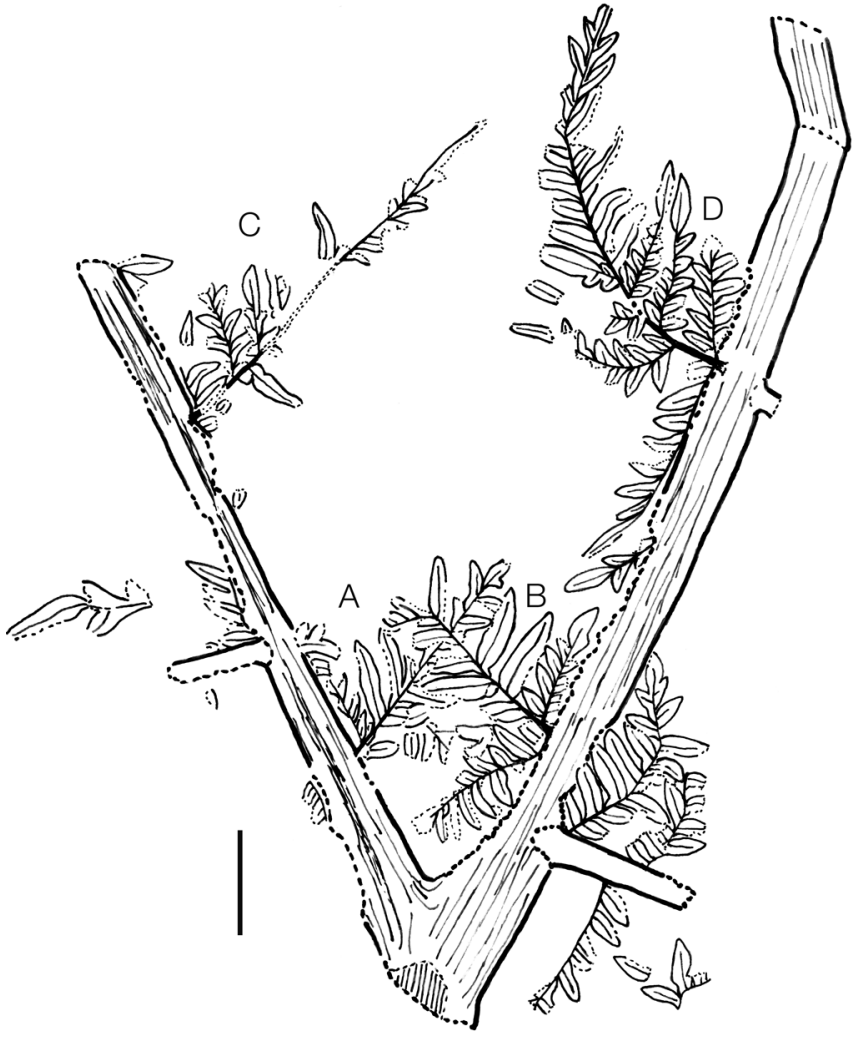

Figure 1. Alethopteris sp. Sketch drawing of specimen MBL 630905; A, B, C, D: small inner secondary pinnae. Scale bar represents $2 \mathrm{~cm}$.

on. Its width changes from $15 \mathrm{~mm}$ proximally to $13 \mathrm{~mm}$ distally. The left primary rachis is preserved for a length of $140 \mathrm{~mm}$; its distal part is not preserved because of preferential splitting of the rock along the plane of a root remain of Radicites H. Potonié, 1893, located below the level of the Alethopteris foliage. The width of the left primary rachis changes from $14 \mathrm{~mm}$ proximally to $8 \mathrm{~mm}$ distally, but the original width was larger because the proximal part of the rachis is broken along its left border. Furthermore, it appears to have been more markedly crushed than the right primary rachis, as attested by the presence of prominent longitudinal compression ribs (Figs 2a, 3a).

Two fragmentary secondary rachides are preserved on the outer side of the right primary rachis. The proximal one, $28 \mathrm{~mm}$ long and $6 \mathrm{~mm}$ wide at the base, is located at $35 \mathrm{~mm}$ from the bifurcation. It bears a few fragmentary last order pinnae. The most proximal one, on the acroscopic side, is the better preserved (Figs 2a, 3e). It is $45 \mathrm{~mm}$ long and comprises at both sides seven lateral

Figure 2. a, photograph at natural size of the specimen. Note the marked longitudinal compression ribs of the left primary rachis. Scale bar represents $2 \mathrm{~cm}$. Origin: Nord/Pas-de-Calais coalfield. Repository: Musée de Géologie, Ville de Lille. b, enlargement (x3) of the lowermost part of the specimen; note the petiolar striae (arrow) oriented in the direction of the bisector of the bifurcation. Scale bar represents $1 \mathrm{~cm}$. c, enlargement (x3) of the proximal outer right secondary rachis, the arrow points to the adaxial insertion of the rachis, which is superimposed by the primary rachis. Scale bar represents $1 \mathrm{~cm}$. 


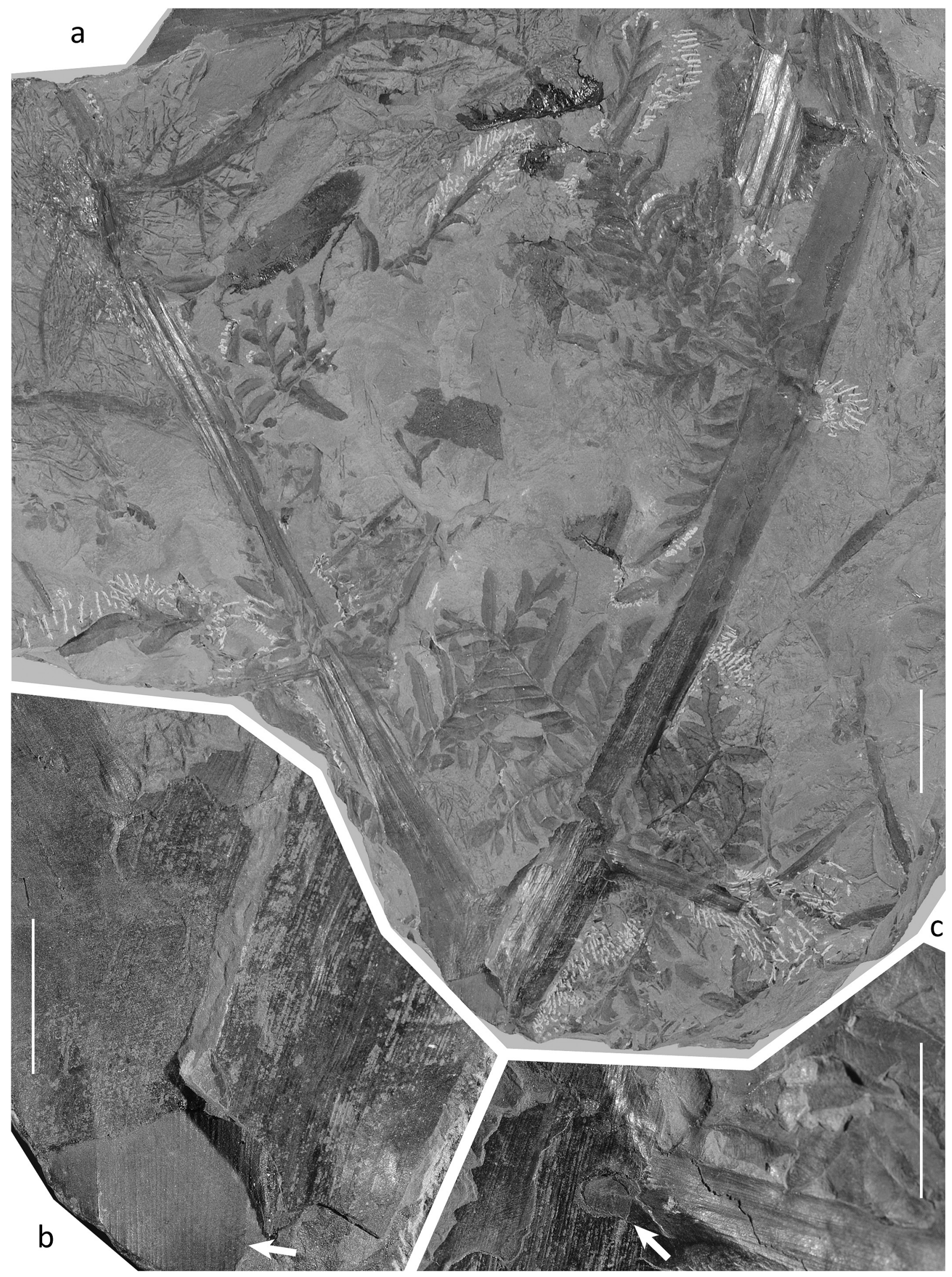


pinnules below a rather short terminal pinnule. The next secondary rachis departure is located at $95 \mathrm{~mm}$ from the first one (Figs 2a, 3b: right-hand side). Unfortunately, it is only preserved for a very short distance: $4 \mathrm{~mm}$. It is $5 \mathrm{~mm}$ wide, with no preserved foliage. These departures were attached adaxially to the primary rachis (Fig. 2c), on the face opposite to the viewer, which explains that some proximal parts of the foliage are covered by the crushed primary rachis (Fig. 3b).

Only one secondary rachis, $20 \mathrm{~mm}$ long and more or less $5 \mathrm{~mm}$ wide, is partly preserved at the external side of the left primary rachis (Figs 2a, 3c, arrow). It bears at its acroscopic side an incomplete ultimate pinna. That secondary departure is slightly plunging into the rock matrix. It is located at $70 \mathrm{~mm}$ from the bifurcation and is, therefore, not quite symmetric to the corresponding right-hand-side secondary rachis. Assuming that the spacing of the outer secondary rachides was the same for both primary rachides, that original asymmetry, together with the shorter preservation of the left primary rachis explains why there is not another external secondary rachis departure visible at the left side of the specimen.

Inside the bifurcation, four secondary pinnae are more or less well preserved, two attached to the left primary rachis (A and C on Fig. 1, moving proximo-distally), and two at the right primary rachis (B and D on Fig. 1). These secondary pinnae are inserted almost symmetrically, A and C respectively at $30 \mathrm{~mm}$ and $104 \mathrm{~mm}$, and $B$ and D at $35 \mathrm{~mm}$ and $110 \mathrm{~mm}$ from the inside of the bifurcation. Because of space constraints, secondary pinnae A and B are shorter and slightly less differentiated than secondary pinnae $\mathrm{C}$ and $\mathrm{D}$.

Secondary pinna B, ca $50 \mathrm{~mm}$ long, is rather nicely preserved, slightly bent downwards in its distal part, with its very apex missing. It bears at both basiscopic and acroscopic sides a single ultimate pinna, followed by several elongate pinnules, the more proximal ones being $18 \mathrm{~mm}$ long and $5 \mathrm{~mm}$ wide (Fig. 3d). The basiscopic ultimate pinna (Figs 1, 2a) of secondary pinna B (with six and ? seven lateral pinnules) is slightly more developed than the acroscopic one (with four lateral pinnules). Unfortunately, the symmetrical secondary pinna $\mathrm{A}$ is not so well preserved, especially at its basiscopic side. However it shows a similar degree of differentiation for its acroscopic side, i.e. a basal ultimate pinna (with four lateral pinnules) followed by several elongate pinnules, evidently diminishing in size where approaching the partly preserved terminal pinnule (Figs 2a, 3d). Secondary pinna A is also ca $50 \mathrm{~mm}$ long. Both secondary pinnae A and $\mathrm{B}$ were inserted at $80^{\circ}$ on their respective primary rachides. They are markedly overlapping (Figs 1, 2a, 3d).
Secondary pinna $\mathrm{D}, c a 85 \mathrm{~mm}$ long, is also rather well preserved, although markedly distorted upwards distally. At both basiscopic and acroscopic sides, respectively, it bears four and three ultimate pinnae, followed on either side by a lobate pinnule and several elongate pinnules, gradually diminishing in size where approaching the partly preserved terminal pinnule. The acroscopic ultimate pinnae are $30 \mathrm{~mm}$ long, and bear four or five lateral pinnules each. The basiscopic pinnae appear more developed than those at the acroscopic side (Figs 2a, 3b). Only the distal part of the first basiscopic pinna is visible, its proximal part being hidden by the superimposed primary rachis. It was $c a 60 \mathrm{~mm}$ long. The next basiscopic ultimate pinna, also partly covered by the primary rachis, is $c a 45 \mathrm{~mm}$ long and bears seven lateral pinnules at its anadromic side. The following basiscopic foliage elements decrease in size and differentiation as usual. The symmetrical secondary pinna $\mathrm{C}$ is not well preserved, especially at its basiscopic side because the rock split in favour of foliage debris of Sphenopteris sp., present on a plane located slightly below that of the Alethopteris specimen (Fig. 2a). Fortunately, the acroscopic side, although not perfectly preserved, is seen to show an approximately similar degree of differentiation as the acroscopic side of secondary pinna D, i.e. with three ultimate pinnae followed by a lobate pinnule (Fig. 3a). More distally, the preservation is defective where approaching the poorly preserved terminal pinnule. Secondary pinna $\mathrm{C}$ is $c a 83 \mathrm{~mm}$ long. Both secondary pinnae $\mathrm{C}$ and $\mathrm{D}$ were also inserted at $80^{\circ}$ on the respective primary rachides. When straightening the distal part of the rachis of secondary pinna $\mathrm{D}$, taphonomically distorted upwards, it appears that the tips of pinnae $\mathrm{C}$ and $\mathrm{D}$ were originally slightly overlapping (Figs 1, 2a).

\section{DISCUSSION}

\section{Morphological comments}

The asymmetry in the insertion of the first outer secondary pinnae, combined with the poorer preservation of the specimen on its left-hand side, might mean that the specimen in hand does not correspond to the main bifurcation of the Alethopteris frond. However, it is not uncommon to find occasionally such kind of asymmetrical specimens for bipartite fronds known to exhibit usually a rather more symmetrical architecture. Good examples are for instance the type specimen of Neuropteris heterophylla (Brongniart, 1831: pl. 71), the type specimen of Laveineopteris guardinis (Grand'Eury, 1890: pl. 22, fig. 2), the specimens of Eusphenopteris scribanii Van Amerom, 1975 and Eusphe-

Figure 3. a, enlargement (x2) of the distal inner left secondary pinna (C on Fig. 1). b, enlargement (x2) of the distal inner right secondary pinna (D on Fig. 1). c, enlargement (x2) of the proximal outer left secondary rachis (arrow). d, enlargement (x2) of the two proximal inner secondary pinnae (A and B on Fig. 1), markedly overlapping. e, enlargement (x2) of the acroscopic proximal ultimate pinna of the proximal right outer secondary pinna. Scale bars represent $1 \mathrm{~cm}$. 


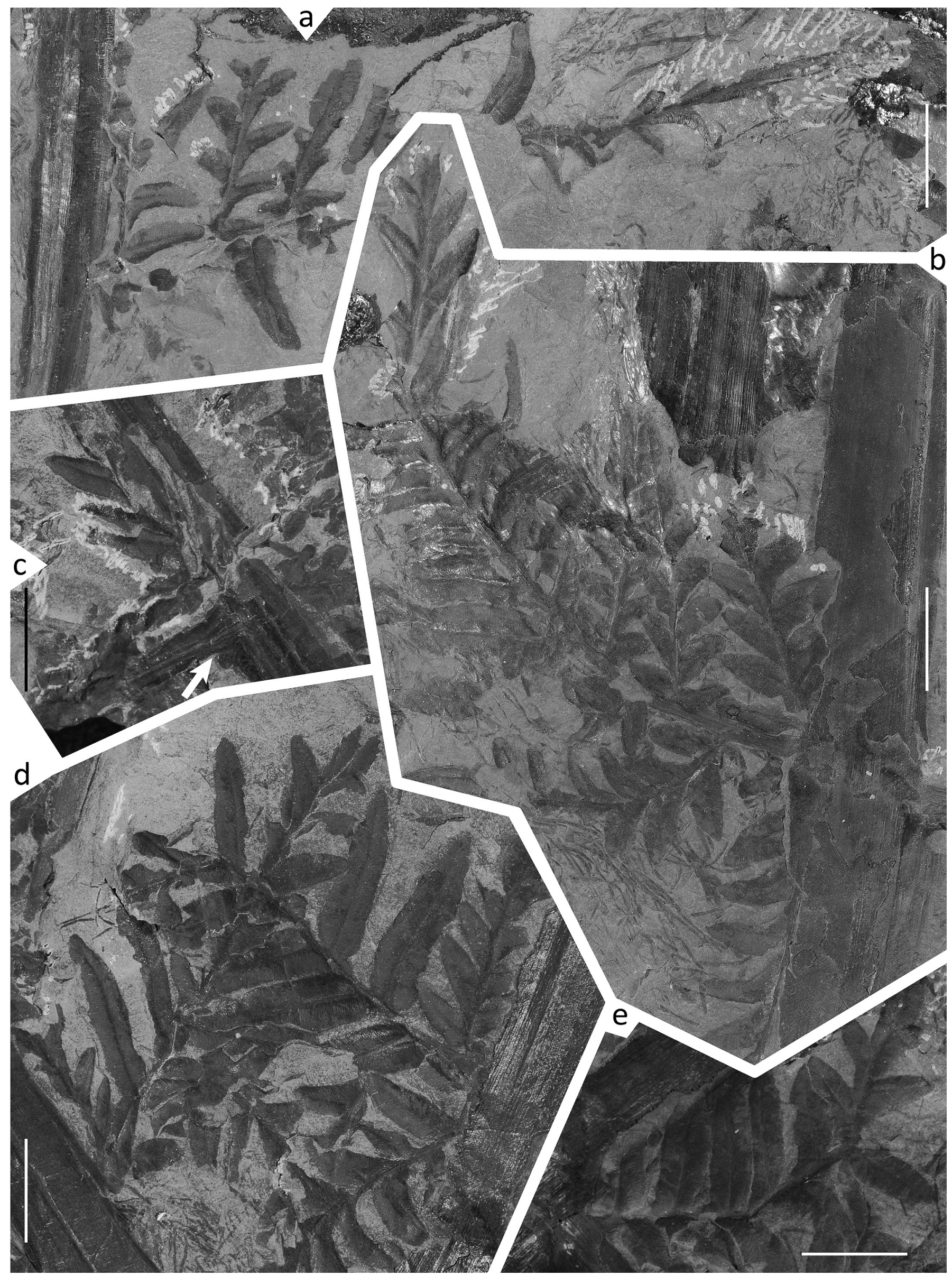




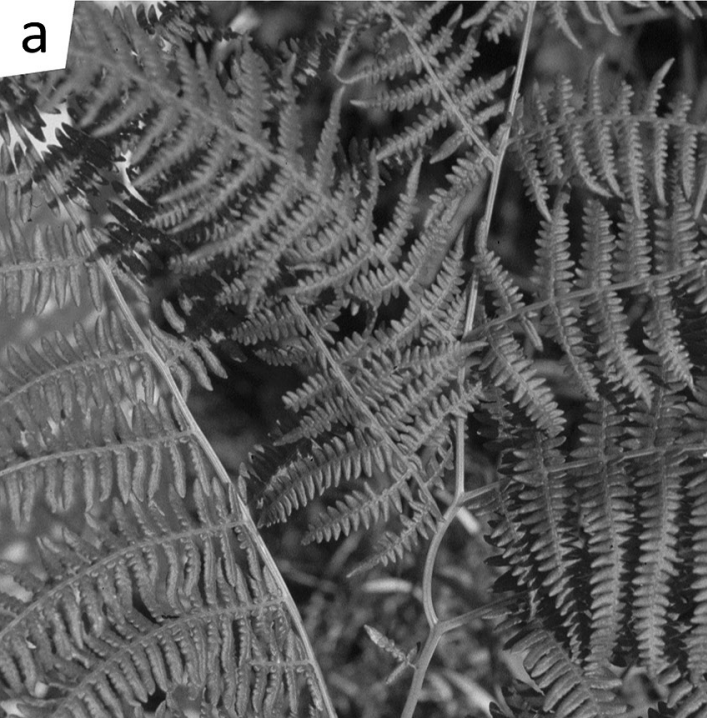
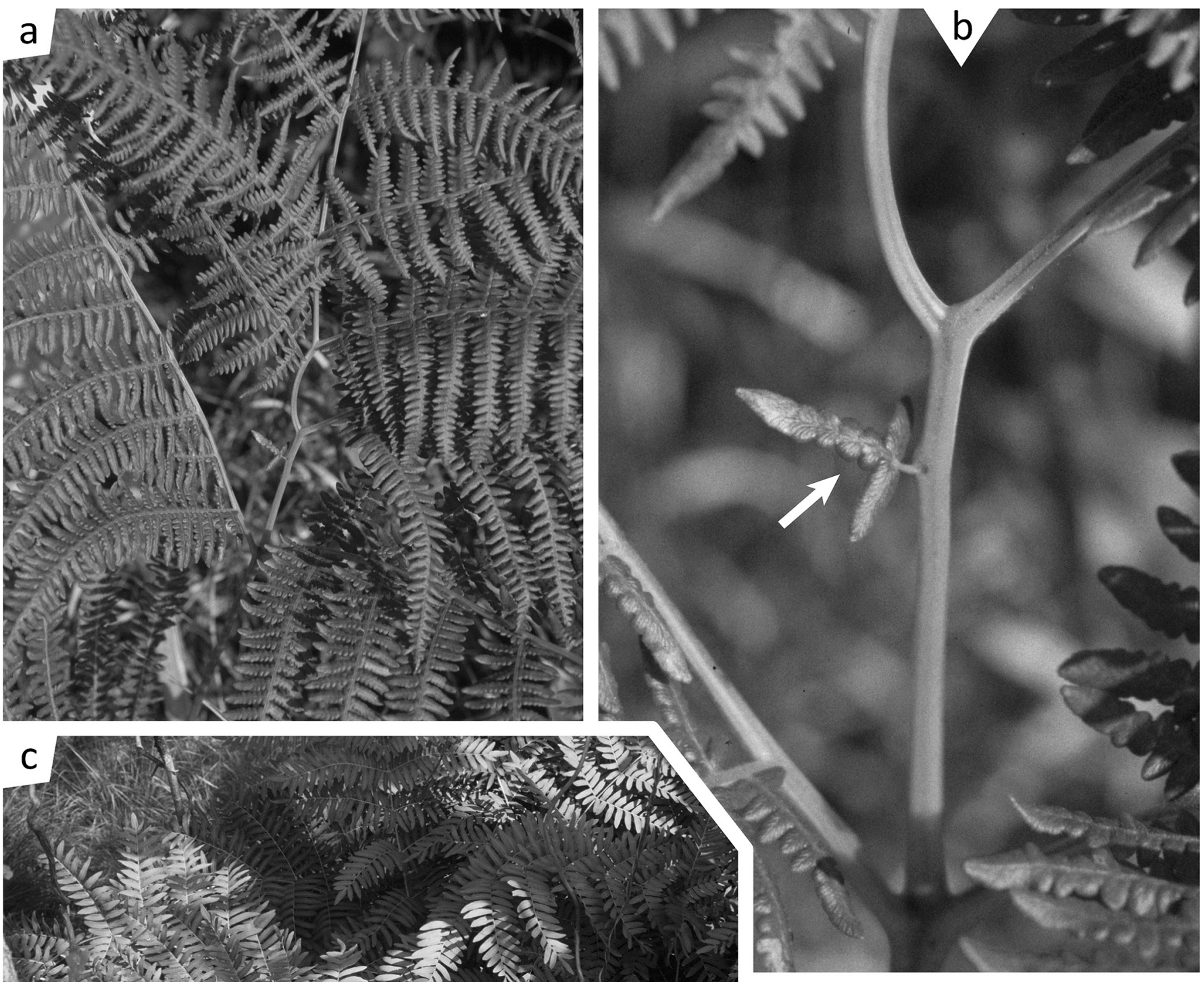

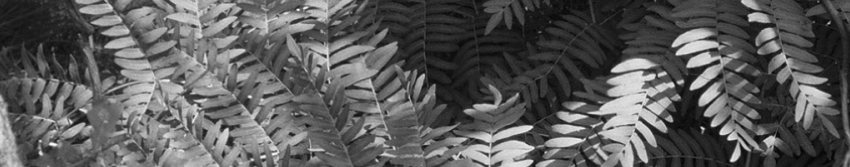

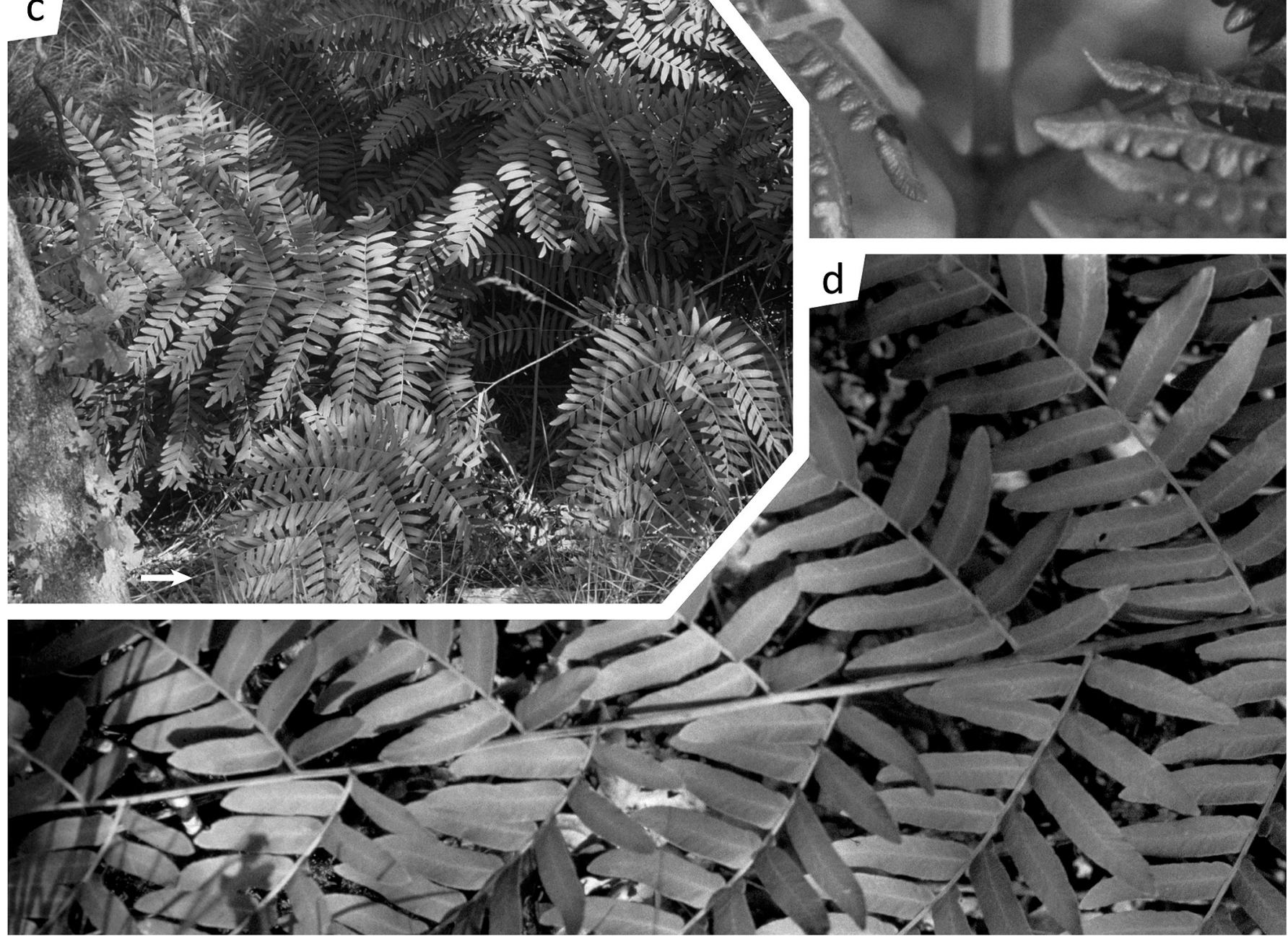


nopteris sp. as illustrated in Laveine (1993: pl. 1, fig. 2, and in pl. 3, fig. 1 respectively). Conversely, the almost symmetrical location of the insertions of the inner secondary pinnae, the similar degree of differentiation of the preserved elements of foliage, and their overlapping along the bisector of the internal angle are clearly in favour of a fundamentally symmetric organisation for the present specimen. It is only unfortunate that the petiole is so incompletely preserved. However, the few petiolar striae visible at the lower part of the specimen (Figs 1, 2b, arrow) are oriented also more or less in the direction of the bisector. Though not wholly conclusive, this reinforces the impression that the specimen corresponds to the main (and only, in the case of Alethopteris) bifurcation of the frond. The general organisation of the present specimen fits the frond reconstruction as proposed in Laveine et al. (1993: text-fig. 3). However, the basal $15 \mathrm{~mm}$-width of the right primary rachis (the best preserved), as compared to the 20 mm-width of the Zeiller (1886: pl. 31) specimen (at a more distal location in the frond), and the $45 \mathrm{~mm}$-width of the primary rachides of the specimen illustrated in Laveine $e t$ al. (1993: pl. 3, fig. 1) does suggest that the specimen in hand corresponds to a rather small size frond. The shorter length of the ultimate pinnae of the present specimen, as compared to the length of the ultimate pinnae of the specimen illustrated in Laveine (1986: pl. 1, fig. 2), i.e. 60 $\mathrm{mm}$ as against $150 \mathrm{~mm}$, also attests to a rather small size frond. This would explain the slightly lesser differentiation of the foliage especially on the outer side (Fig. 3e), as compared to the reconstruction proposed in Laveine $e t$ al. (1993: text-fig. 3).

\section{Taxonomical comments}

The general outline and the rather poorly preserved venation of the pinnules of the present specimen suggest an assignment to Alethopteris lonchitica (Schlotheim, 1804, 1820), as understood by Zeiller (1886-1888) for specimens from northern France. However, Wagner \& ÁlvarezVázquez (2008) reappraised the characteristics of the taxon as figured by Zeiller, and concluded that it corresponded to Alethopteris urophylla (Brongniart, 1834) Goeppert, 1836.

\section{GENERAL CONSIDERATIONS}

\section{General morphological considerations}

Zodrow (2002: fig. 18, and 2007: fig. 16) presented sketch drawings of an alethopterid tree carrying fronds exhibiting a main symmetrical bifurcation, and also some large foliage segments inserted well down on the petiole, below the main bifurcation. That reconstruction is based on rachis remains (Zodrow, 2002: fig. 9) showing an "Y axis" with several short rachial departures. Conversely, another specimen (Zodrow, 2002: figs 3, 4) shows, in organic connection to the stem, several naked petioles, i.e. with no rachial departures for a distance of at least $60 \mathrm{~cm}$ from the base, as is emphasized by Zodrow (2002: 192). Consequently, there is some discrepancy in the information provided by these two specimens. Unfortunately, all the rachides of large dimensions recorded from the site by Zodrow (2002) are devoid of attached foliage remains, thus leaving the usual uncertainty as to the correct taxonomic assignment of the rachides. It is known, for instance for the genus Eusphenopteris Simson-Scharold, 1934, that some bipartite fronds may (e.g. Zeiller, 1886: pl. 4, fig. 1; pl. 5, figs 1-2) or may not (e.g. Laveine, 1993: pl. 3, fig. 2; pl. 5, fig 1) bear some lateral secondary pinnae on the petiole, but such a possibility remains to be determined for the genus Alethopteris. The lack of a preserved petiole for the specimen in hand implies a lack of information in this respect. The few known specimens of fronds belonging to genera of the same natural group (e.g. Neuralethopteris, Cardioneuropteris), with a partly preserved petiole and with some remains of foliage attached, all show naked petioles.

Zodrow (2002: 187) suggested that 'intercalated pinnate structures' may possibly be present in the Alethopteris frond, but this suggestion is also based on association, the remains of ramifications being devoid of attached foliage. The taxonomic assignment is, therefore, disputable. In some cases, because of a marked adaxial insertion of secondary rachides (e.g. Buisine, 1961: pl. 13, fig. 1, reillustrated in Wagner \& Álvarez-Vázquez, 2008: figs 8-9), it may appear, when the fossil remain is seen from the abaxial side, that some ultimate pinnae are directly attached to the corresponding primary rachis (e.g. Figs 1, 2a, 3b). However, this corresponds clearly to a taphonomic effect, with the primary rachis partly covering the most proximal part of the secondary rachides and, consequently, hiding the basiscopic part of the proximal ultimate pinnae. This point has been made before (e.g. Buisine, 1961: pl. 34, explanation of figure 1). Of course, it is not excluded that a fossil remain of Alethopteris might be recorded some day showing a rachial intercalated pinna, such as for the specimen of the recent fern Pteridium aquilinum (Linné, 1753) Kuhn, 1879, illustrated here (Figs 4a, b, arrow), but this is theoretical. Such cases are very rare teratological cases,

Figure 4. a, partial view of a frond of Pteridium aquilinum (Linné, 1753) Kuhn, 1879. b, middle part of the same specimen: probably because of a trauma, the lateral secondary pinna at the left side (arrow), which should have been normally tripinnatifid, has remained at a restricted unipinnate stage. c, view of a plant of Osmunda regalis Linné, 1753 showing several mature fronds. $\mathbf{d}$, one frond of the same plant, pointed by the arrow on figure 4c, exhibiting alternate insertions of the lateral secondary rachides, conversely to the other fronds of the same plant, with opposite insertions of the secondary rachides. Southwestern France, La Teste area near Arcachon. 


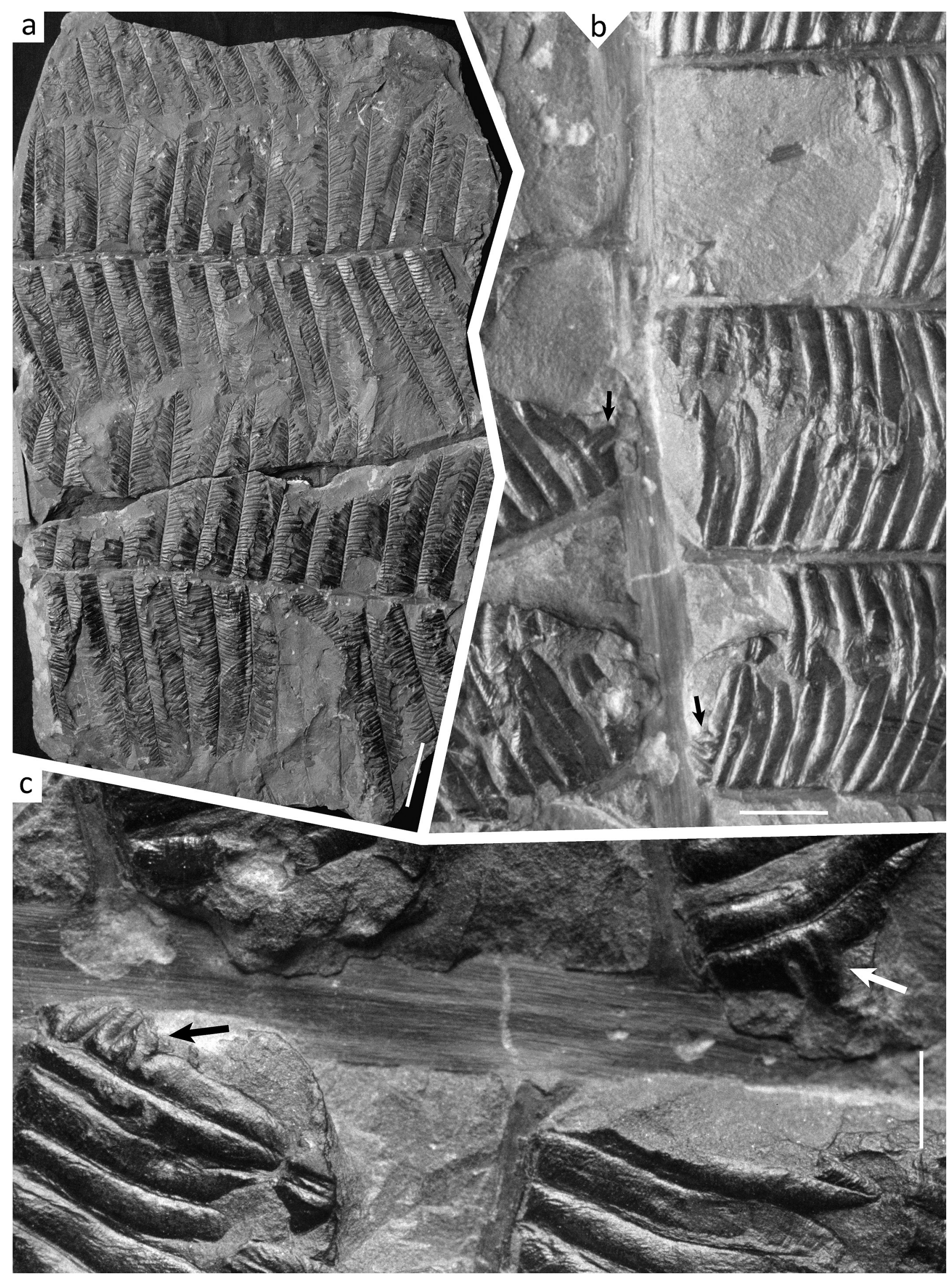


with normally only a minute chance to being preserved as fossils. Another example is given here (Figs 4c, arrow, 4d) of a plant of Osmunda regalis Linné, 1753, with a frond showing secondary pinnae inserted alternately, whereas the other fronds of the same plant show the usual habit, with secondary pinnae oppositely attached (Fig. 4c). Another exceptional teratological case of development is presented in Josten et al. (2001: pls 1-6) for a calamitalean remain. Such teratological modifications never justify discarding the general diagnostic characteristics of the corresponding taxa. Obviously, all the large, rather numerous remains now available of true Alethopteris foliage (excluding, of course, those belonging to Callipteridium Weiss, 1870) attest clearly that the lack of rachial intercalated elements on the primary and secondary rachides is the normal, usual condition for Alethopteris.

A last morphological characteristic worthwhile being discussed is the degree of foliage differentiation of the Alethopteris frond. The proposed reconstruction in Laveine et al. (1993: text-fig. 3) shows a quadripinnate stage of differentiation in the proximal part of the primary pinnae, principally on the outer side. Unfortunately, the present specimen corresponds to a frond of rather small size. Even if better preserved, it would be unlikely to provide additional information of substance in this matter. As mentioned earlier, it is far from easy to record accurate specimens, and it is practically impossible to find such specimens for all the Alethopteris species. Despite the large amount of large specimens of Alethopteris stored in the collections of the Lille Museum of Geology there is only one specimen (MBL 19116) that brings slight information on that point (Fig. 5). It belongs to the Alethopteris missouriensis D. White, 1899, complex (see Wagner \& ÁlvarezVázquez, 2008, for recent taxonomical considerations on this matter). The specimen shows three parallel fragments of large secondary pinnae. The parallel course of the two secondary rachides visible suggests that they were inserted on a common primary rachis, unfortunately not preserved (Fig. 5a). As a matter of consequence, that fossil remain appears at first sight tripinnate. However, a close examination of the long 'ultimate' pinnae of the specimen reveals that some basal 'pinnules' show a beginning of lobation (Figs 5b, 5c, arrows), thus attesting indisputably to a beginning of quadripinnatifid stage of foliage differentiation for the corresponding primary pinna (according to the terminology for frond architecture used in Laveine, 1997). Otherwise, for all the other specimens available showing a gradual differentiation of pinnules into ultimate pinnae (e.g. Wagner \& Álvarez-Vázquez, 2008: figs 2,9) it is impossible to decide on the true location of these specimens. They may either be close to the apex of the corresponding primary pinna (which is the more likely), or close to the apex of a proximal outer secondary pinna of a huge frond. It is therefore impossible to conclude safely on the degree of segmentation of the corresponding fronds.

\section{General taxonomical and palaeogeographical conside- rations}

According to the general outline of the pinnules, with a marked decurrent deltoid base, and to the aspect of their venation, the present bifurcate specimen must be assigned to Alethopteris urophylla, as re-described by Wagner \& Álvarez-Vázquez (2008). Incidentally, it brings the opportunity to reappraise both a general taxonomical and palaeogeographical point dealt with by Wagner \& Álvarez-Vázquez (2008). These authors (2008: 170, bottom of the left column) mentioned in the specimens excludenda the specimen illustrated by Laveine et al. (2003: pl. 10, fig. 1) as Alethopteris cf. lonchitica, and representing the distal part of an ultimate pinna. The specific assignment of the single specimen recorded being proposed with reservation in Laveine et al. (2003), it would be endless to discuss on the full accuracy of that specific assignment. However, Wagner \& Álvarez-Vázquez (2008) suggesting a possible relationship of the specimen with Neuropteris obliqua (Brongniart, 1833) Zeiller, 1888 sensu lato, it implies that the generic assignment is also disputed. The suggested relationship with Neuropteris obliqua is not satisfactory. The marked catadromic attachment of the lamina of the few lateral pinnules preserved is indisputably of Alethopteris type, as well as the marked midvein with its attachment slightly shifted toward the anadromic side of the pinnule. It is never the case for Neuropteris obliqua, for which the midvein is always only faintly marked, and always strongly decurrent for the pinnules at such a distal location. Definitely, if the specific assignment can be questioned, this is not the case for the generic assignment. This point would not have been worthy of discussion here, were it not linked with another point discussed in Wagner \& Álvarez-Vázquez (2008: 166) contesting, albeit implicitly, the presence of the genus Alethopteris in China. Therefore, it is necessary to emphasize that another specimen of Alethopteris illustrated in Laveine et al. (2003: pl. 18, fig. 1), also questionable as to its specific assignment,

Figure 5. a, large frond fragment of Alethopteris missouriensis D. White, 1899, showing three large parallel fragments of secondary pinnae more or less well preserved, and very likely inserted on a common primary rachis, not preserved. Scale bar represents 5 cm. Origin: Nord/Pas-de-Calais coalfield, Fouquières-les-Lens, seam Marcel, Faisceau d'Ernestine, Upper Bolsovian. Repository: Musée de Géologie, Ville de Lille, accession n ${ }^{\circ}$ MBL 19116. b, enlargement of the right-hand part of the lowermost secondary pinna of the same specimen, the arrows point to the elements enlarged on figure $5 \mathrm{c}$. Scale bar represents $1 \mathrm{~cm}$. c enlargement of the right part of the lowermost secondary pinna in the vicinity of the secondary rachis, the two arrows points to some lobate 'pinnules', attesting to a beginning of quadripinnatifid stage of differentiation. Scale bar represents $5 \mathrm{~mm}$. 
exhibits characteristics rendering totally indisputable the generic assignment. Therefore, it can be safely concluded that the genus Alethopteris, as well as the genus Lonchopteris Brongniart, 1828 (Zhang et al., 1993: pls 19-20), although rarely recorded, are definitely present in the Pennsylvanian (Upper Carboniferous) deposits (and also in the lowermost Permian deposits for Alethopteris) of Northwest China. The paucity of records is clearly linked with the fact that it concerns remote areas difficult to access. There is little doubt that future investigations will extend the general palaeogeographical distribution of these genera, as ultimately concluded also by Wagner \& ÁlvarezVázquez (2008: 181).

\section{SUMMARY AND CONCLUSION}

The specimen subject of the present paper brings a definite argument attesting to the bipartite architecture of the frond for the genus Alethopteris, a characteristic which remained until now to be formally established. Despite the fact that Alethopteris is abundantly recorded from the Pennsylvanian deposits in the Euramerican area, experience shows that it is far from easy to find significant specimens recording its organization. Now a bipartite architecture has been proved for one of the most common species of Alethopteris, it means that the large specimen of Alethopteris dealt with in Laveine (1986) is only part of one of the two symmetrical primary pinnae of the frond. Accordingly, it can now be firmly concluded that the large fronds of Alethopteris may have reached a width of about four metres.

\section{ACKNOWLEDGEMENTS}

We are much indebted to Dr. Paul C. Lyons, Research Geologist (retired), U.S. Geological Survey, for his help in reviewing the initial version of the manuscript and for improving its English. We are also very grateful to Mr. Pascal De Bleeckere (Musée d'Histoire naturelle de Lille) for the realization of the photographs, and for the computerization of all the illustrations. The agreement of Mr. Bertrand Radigois, Chief Curator, for using freely of the technical facilities of the Musée d'Histoire naturelle de Lille, is also gratefully acknowledged. We thank also very much Professor Dr. Robert H. Wagner (Jardín Botánico de Córdoba, Spain) and Dr. Christopher J. Cleal (National Museums and Galleries of Wales, Cardiff, U.K.) for their celerity in the formal reviewing of the manuscript. Their scrupulous and fruitful critical comments were highly appreciated.

\section{REFERENCES}

Amerom, H.W.J. Van 1975. Die eusphenopteridischen Pteridophyllen aus der Sammlung des geologischen Bureaus in Heerlen, unter besonderer Berücksichtigung ihrer
Stratigraphie bezüglich des südlimburger Kohlenreviers. Mededelingen Rijks Geologische Dienst, Serie C-III-1 (7), 1-208, pls I-XLVIII.

Brongniart, A. 1828-1837. Histoire des végétaux fossiles. Dufour et d'Ocagne éd., Paris, I, 1-488, pls 1-166.

Buisine, M. 1961. Contribution à l'étude de la flore du Terrain houiller. Les Aléthoptéridées du Nord de la France. I - Flore fossile. Etudes géologiques pour l'Atlas de Topographie souterraine, $H B N P C, 4,1-317$, pls I-LXXIV.

Cremer, L. 1893. Über die fossilen Farne des westfälischen Carbons und ihre Bedeutung für eine Gliederung des letzteren. Mitteilungen aus dem geologischen Museum der westfälischen Berggewerkschaftskasse, 1-49, pls I-III.

Goeppert, H.R. Von 1836. Die fossilen Farnkraüter. Verhandlungen der Kaiserlischen Leopoldinisch Carolinischen Akademie der Naturforscher, XXII Supl., 1-299, pls I-XLIV.

Goganova, L.A., Laveine, J.-P., Lemoigne, Y. \& Durante, M. 1993. General characteristics of the Carboniferous pteridosperm Cardioneuropteris Goganova et al., from the Uppermost Visean strata of Kuucheku colliery near Karaganda, Central Kazakhstan, CIS. Revue de Paléobiologie, vol. sp. 6, 169-219, pls 1-19.

Grand'Eury, C. 1890. Géologie et paléontologie du bassin houiller du Gard. Théolier et Cie éd., Saint-Étienne, 1-354, pls I-XXII.

Josten, K.H., Laveine, J.-P. \& Van Amerom, H.W.J. 2001. Eine Calamiten-Modifikation aus dem Oberkarbon. Geologie und Paläontologie in Westfalen, 58, 67-85, pls 1-7.

Laveine, J.-P. 1967. Contribution à l'étude de la flore du terrain houiller. Les Neuroptéridées du Nord de la France. I - Flore fossile. Etudes géologiques pour l'Atlas de Topographie souterraine, HBNPC, 5, 1-344, pls A-P, I-LXXXIV.

Laveine, J.-P. 1986. The size of the frond in the genus Alethopteris Sternberg. Geobios, 19, 49-56, pl. I.

Laveine, J.-P. 1993. Frond architecture, phyllotaxy and general habit of some representatives of the genus Eusphenopteris Simson-Scharold, Carboniferous pteridosperm. Douzième Congrès International de Stratigraphie et de Géologie du Carbonifère et du Permien, Buenos Aires 1991, Comptes Rendus, 2, 73-88, pls 1-5.

Laveine, J.-P. 1997. Synthetic analysis of the Neuropterids. Their interest for the decipherment of Carboniferous palaeogeography. Review of Palaeobotany and Palynology, 95, 155-189.

Laveine, J.-P., Belhis, A., Lemoigne, Y. \& Zhang, S. 1993. Frond architecture in the genera Neuralethopteris Cremer, Alethopteris Sternberg and Lonchopteris Brongniart (Carboniferous pteridosperms). Revue de Paléobiologie, vol. sp. 6, 149-166, pls 1-3.

Laveine, J.-P., Zhang, S., Liu, L., An, D., Zheng, Q., Cao, J. \& Lemoigne, Y. 2003. The late Palaeozoic floras of the Hotan area (Xinjiang Uygur Autonomous Region, Northwest China), and their palaeogeographical significance. Revue de Paléobiologie, 22, 473-559, pls I-XX.

Potonié, H. 1893. Die Flora des Rotliegendes von Thüringen. Königlisch Preussischen geologischen Landesanstalt (N.F.), 9, 1-298, tab. I-II, pls I-XXXIV. 
Schlotheim, E.F. Von 1804. Beschreibung merkwürdiger Kraüter-Abdrücke und Pflanzen-Versteinerungen (Ein Beitrag zur Flora der Vorwelt). Gotha, 1-68, pls I-XIV.

Schlotheim, E.F. Von 1820. Die Petrefactenkunde auf ihrem jetzigen Standtpunkte, durch die Beshreibung seiner Sammlung versteinerter und fossiler Überreste des Thierund Pflanzenreichs der Vorwelt erläutert. Gotha, i-lxii (Einleitung), 1-437, pls I-XXXVI.

Simson-Scharold, E. 1934. Zur Kenntnis der Carbonflora des Saargebietes. Palaeontographica, Stuttgart, B, 79, 1-66, pls I-VII.

Sternberg, K. Von 1820-1838. Versuch einer geognostischbotanischen Darstellung der Flora der Vorwelt. C.E. Brenck's Wittwe ed., Regensburg, I, 1 (1820): 1-24, pls I-XIII; 2 (1822): 1-33, pls XIV-XXVI; 3 (1823): 1-40, pls XXVII-XXXIX; 4 (1825): 1-48, pls XL-LIX, A-E; II, J. Spurny ed., Prag, 5-6 (1833): 1-80, pls I-XXVI; 7-8 (1838, Presl): 81-220, I-LXXI, pls XXVII-LVIII.

Wagner, R.H. \& Álvarez-Vázquez, C. 2008. A revision of the lower Pennsylvanian Alethopteris lonchitica (auctorum) and its identity with Alethopteris urophylla. Revista Española de Paleontología, 23, 157-192.

Weiss, C.E. 1869-1872. Fossile Flora der jüngsten Steinkohlenformation und des Rotliegenden im Saar-Rhein-Gebiete. Vorlag A. Henry, Bonn, text (1869), 1-250, Atlas (18691872), pls I-LXXIII.
White, D. 1899. Fossil Flora of the Lower Coal Measures of Missouri. United States Geological Survey, Monographs, XXXVII, 1-467, pls I-LXXIII.

Wnuk, C. \& Pfefferkorn, H.W. 1984. The life habits and paleoecology of Middle Pennsylvanian medullosan pteridosperms based on an in situ assemblage from the Bernice basin (Sullivan County, Pennsylvania, U.S.A.). Review of Palaeobotany and Palynology, 41, 329-351.

Zeiller, R. 1886-1888. Bassin houiller de Valenciennes. Description de la flore fossile. Etudes des Gîtes minéraux de la France, Texte (1888), 1-731; Atlas (1886): pls I-XCIV.

Zhang, S., Huo, F., Cao, J., Liu, Z., Laveine, J.-P \& Lemoigne, Y. 1993. The Carboniferous flora of the Zhongning district, Ningxia Region, North China. Revue de Paléobiologie, vol. sp. 6, 1-93, pls 1-29.

Zodrow, E.L. 2002. The "medullosalean forest" at the Lloyd Cove Seam (Pennsylvanian, Sydney Coalfield, Nova Scotia, Canada). Atlantic Geology, 38, 177-195.

Zodrow, E.L. 2007. Reconstructed tree fern Alethopteris zeilleri (Carboniferous, Medullosales). International Journal of Coal Geology, 69, 68-89.

Manuscrito recibido: 29 de Junio, 2009 Manuscrito aceptado: 15 de Septiembre, 2009 
